\title{
Epidemiology of squamous cell carcinomas in rudd Scardinius erythrophthalmus from SE Ireland
}

\author{
Chutima Hanajavanit ${ }^{1}$, Mairead Bermingham ${ }^{2}$, Máire F. Mulcahy ${ }^{2, *}$ \\ ${ }^{1}$ Department of Biology, Faculty of Science, Khon Kaen University, 40002, Thailand \\ ${ }^{2}$ Department of Zoology, Ecology and Plant Science, National University of Ireland, North Mall Campus, Cork, Ireland
}

\begin{abstract}
An epidemiological study was carried out to investigate the possible aetiology of squamous cell carcinomas which occur in a population of rudd Scardinius erythrophthalmus (L.) from Lough Aderry in south-east Ireland. A total of 1343 rudd were sampled from Lough Aderry and 2 nearby small lakes in spring, summer, autumn, and winter over $2 \mathrm{yr}, 1986$ to 1988. Fish were weighed, measured, sexed, aged, and examined for lesions. Water quality parameters and natural radioactivity were assessed as possible influencing factors in the disease. The prevalence of squamous cell carcinoma was $6.1 \%$ overall, with no significant difference between the lakes, seasons or years. Both male and female fish were affected, of ages from $1+$ to $5+\mathrm{yr}$. No fish of $6+$ or $7+$ yr was found with tumours, indicating that the neoplasm caused premature death. The female:male sex ratio of rudd with tumours was higher than that of healthy rudd overall, suggesting that males are more susceptible to the neoplasm. Of the parasites observed, Posthodiplostomum cuticola was common, but rarely found in rudd with tumours. Sphaerospora sp.was also common, but not in sufficient densities for statistical inference, and Argulus sp. was present on 7 fish. No viral particles were found. Natural radiation levels in the vicinity of the lakes were low. The lakes sampled are in an agricultural catchment, and the waters were eutrophic. While rudd are tolerant, it is likely that environmental conditions were stressful at least some of the time, with possible consequences for the immunocompetence of the rudd. The aetiology of the carcinoma is still unknown, but the possibilities of carcinogenic compounds resulting from the high nutrient levels, or of carcinogenic algal toxins produced during algal blooms, should be examined.
\end{abstract}

KEY WORDS: Squamous cell carcinoma $\cdot$ Rudd $\cdot$ Length $\cdot$ Age $\cdot$ Sex $\cdot$ Environmental parameters

\section{INTRODUCTION}

Squamous cell carcinoma in a population of rudd Scardinius erythrophthalmus (L.) from Lough Aderry in south-east Ireland was first reported by Hanjavanit et al. (1990). Tumours were usually oval or hemispherical in shape, globular, up to $1.1 \times 1.4 \mathrm{~cm}$ in size, raised from the body surface, and firm to the touch. They were deep reddish-brown in colour. The histopathology and ultrastructure are described by Hanjavanit \& Mulcahy (2004). In the early stage, tumour cells appeared singly or in clusters close to the epidermis; later, tumour cells were seen in the dermis as epithelial pearls/nests, cords or sheets with central keratin, which stained with anti-cytokeratin.
With further development of the neoplasm, the tumours appeared as large sheets and masses enclosing extensive keratinous formations, infiltrating deeper into the dermis and penetrating the muscle layers. In some cases metastases were observed in the viscera. Electron microscopic examination showed that the neoplastic cells were jointed by desmosomes. While it was possible to transmit the squamous cell carcinoma experimentally to healthy rudd, using intradermal inoculation of tumour cells, no evidence of virus was found either by electron microscopy, or by preliminary experiments using inoculation of cell-free tumour preparations (Hanjavanit \& Mulcahy 2004). Couch \& Harshbarger (1985) and Harshbarger et al. (1993) proposed that globular skin tumours appear to 
be environmental rather than viral in aetiology. Chemical contaminants in the water have been suggested as associated with the elevated tumour incidence (Black et al. 1982, Malins et al. 1984). Brown et al. (1973) stated that the presence of water pollution may enhance carcinogenesis in fish.

The epidemiology of the neoplasm in rudd in Lough Aderry and in 2 nearby lakes was investigated over a period of 25 mo. This paper (1) reports on the prevalence of the tumours in rudd from the 3 lakes, (2) examines the relationship between the prevalence of the neoplasm and the size, age and sex of the fish and the season, and (3) examines the possible roles of water quality, natural radiation and parasitic infection in the disease. Natural radiation was examined because of regional concerns about radiation levels following the Chernobyl disaster.

\section{MATERIALS AND METHODS}

Fish samples. Preliminary samples of rudd were taken from Lough Aderry (Irish Grid Reference [IGR] W9473) and from Ballyhonock Lake (IGR W9973), east Cork, in January 1986. Subsequently, rudd were sampled 4 times a year in spring, summer, autumn and winter, from Lough Aderry, from Ballyhonock Lake and from College Lake (IGR W9674) between August 1986 and August 1988. All fish were caught in fyke nets and transported alive to the laboratory. They were anaesthetised in a solution of 2-phenoxyethanol before autopsy, and were examined for macroscopic external and internal lesions. Fork length $(\mathrm{cm})$, weight $(\mathrm{g})$, lesions, and parasites were recorded. Scales were removed for scale reading. Whole fish were fixed in Bouin's fixative for $24 \mathrm{~h}$, the abdominal cavity having been opened to facilitate the fixation. The fish were then stored in $70 \%$ alcohol.

Histological preparation. When the sample size was smaller than 50 fish, all rudd were processed for histological examination; when the sample size was greater than 50, all neoplastic and 20 to 25 unaffected rudd were processed. Small tissue pieces from the skin lesions and from the visceral organs, including intestine, liver, pancreas, spleen, kidney and gonad, were prepared for light microscopy and electron microscopy (Hanjavanit \& Mulcahy 2004) . The fish were all sexed, either from histological sections or from macroscopic examination. All fish were aged by scale reading.

Water quality. Water samples were taken in each season, i.e. 4 times a year, at 2 sites from each lake: Ballyhonock Lake and Lough Aderry were sampled from April 1986 to October 1988, and College Lake from October 1986 to October 1988. The samples were taken from the surface $30 \mathrm{~cm}$, usually between 11:30 and 13:00 h, and collected in polythene bottles, except for oxygen determination, when the samples were obtained by overfilling $250 \mathrm{ml}$ borosilicate glass bottles. Air and water temperatures were recorded using a mercury thermometer. $\mathrm{pH}$ was measured on site using a portable $\mathrm{pH}$ meter (WTW). Immediately following collection, water samples were transported to the laboratory for analysis of dissolved oxygen (DO), biochemical oxygen demand (BOD), nitrate, phosphate and chlorophyll a (American Public Health Association 1985), alkalinity, total hardness, calcium hardness, and ammonia (Mackereth et al. 1978).

Soil radioactivity. Soil samples were collected in August 1988 from permanent pasture near each of the 3 lakes. The soil samples were taken from below grass root level (5 to $10 \mathrm{~cm}$ deep), dried at $100^{\circ} \mathrm{C}$ for $24 \mathrm{~h}$ and sieved through a $2 \mathrm{~mm}$ sieve to remove pebbles. Sieved samples, approximately $1 \mathrm{~kg}$ each, were dispatched to the Department of Pure and Applied Physics, Trinity College, Dublin, for measurement of radioactivity. All measurements were made by high resolution gamma spectrometer; the detector was an Ortec hyperpure germanium crystal followed by a standard multichannel analyser.

Statistical analysis. Data were analysed using Kolmogorov-Smirnov/Shapiro-Wilk normality tests, Levene's homogeneity of variance test, 1-way ANOVA, Tukey-Kramer test, simple regression, and stepwise (backward elimination) multivariate regression analysis. When assumptions of ANOVA were not met before or after data transformation (utilizing either $\log _{10}[x]$, $V_{X}, x^{2}$, or $1 / x$ transformation) the nonparametric Kruskal-Wallis and chi-square tests were conducted. Results were given at the $5 \%$ level of significance. The seasons were divided evenly among the months (spring: February to April; summer: May to July; autumn: August to October; and winter: November to January). All tests were performed using the SPSS 11.0 statistical package.

\section{RESULTS}

\section{Prevalence of squamous cell carcinomas}

Gross examination of the body surface and fins revealed single or multiple oval, raised, red/brown lesions, which, following histological examination, were classified as squamous cell carcinomas. The prevalence of these skin tumours in rudd sampled was $3.7 \%(10 / 270), 6.7 \%(41 / 610)$ and $0.9 \%(4 / 463)$ at Ballyhonock Lake, Lough Aderry and College Lake, respectively (Table 1). However, the prevalence of skin tumours did not differ significantly among the sample lakes $(\mathrm{p}>0.05)$. 
Table 1. Scardinius erythrophthalamus. Significant variance observed in prevalence of skin and visceral tumours among the different rudd sizes $(n=50, d f=2,48)$, ages $(n=23, d f=3,20)$, years $(n=25, d f=2,23)$, tumour age/size ranges $(n=16, d f=2,14)$, and parasite prevalence between the lakes $(\mathrm{n}=25, \mathrm{df}=2,23)$ in the $1986-1988$ data set (test assumptions met of normality and homogeneity of variance; $F \geq 3.63$, significant variation at $\mathrm{p} \leq 0.05, \chi^{2} \geq 5.99$ )

\begin{tabular}{|c|c|c|c|c|c|c|}
\hline \multirow[t]{2}{*}{ Parameter } & \multicolumn{2}{|c|}{ ANOVA } & \multicolumn{2}{|c|}{ Kruskal-Wallis test } & \multicolumn{2}{|l|}{ Tukey's test } \\
\hline & $F$ & $\mathrm{p}$ & $\chi^{2}$ & $\mathrm{p}$ & Comparison & $\mathrm{p}$ \\
\hline \multicolumn{7}{|l|}{ Size } \\
\hline Fish sampled & 58.22 & 0.000 & - & - & $\begin{array}{c}5.0-10.9 \text { vs. } 11.0-15.9 \mathrm{~cm} \\
11.0-15.9 \text { vs. } 16.0-21.9 \mathrm{~cm}\end{array}$ & $\begin{array}{l}0.000 \\
0.000\end{array}$ \\
\hline Visceral tumours & 12.90 & 0.002 & 11.73 & 0.003 & $\begin{array}{l}5.0-10.9 \text { vs. } 11.0-15.9 \mathrm{~cm} \\
11.0-15.9 \text { vs. } 16.0-21.9 \mathrm{~cm}\end{array}$ & $\begin{array}{l}0.001 \\
0.003\end{array}$ \\
\hline \multicolumn{7}{|c|}{ 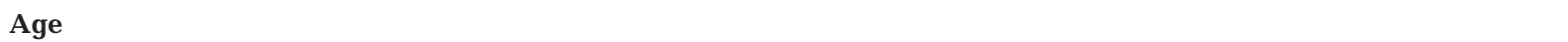 } \\
\hline Fish sampled & 14.19 & 0.000 & - & - & $\begin{array}{l}0-1 \text { vs. } 2-3 \mathrm{yr} \\
2-3 \text { vs. } 4-5 \mathrm{yr} \\
2-3 \text { vs. } 6-7 \mathrm{yr} \\
4-5 \text { vs. } 6-7 \mathrm{yr}\end{array}$ & $\begin{array}{l}0.001 \\
0.020 \\
0.000 \\
0.035\end{array}$ \\
\hline \multicolumn{7}{|l|}{ Site } \\
\hline Posthodiplostomulum cuticola & 11.48 & 0.000 & 15.22 & 0.000 & $\begin{array}{l}\text { Ballyhonock vs. Lough Aderry } \\
\text { Lough Aderry vs. College }\end{array}$ & $\begin{array}{l}0.026 \\
0.000\end{array}$ \\
\hline Sphaerospora sp. & 20.44 & 0.000 & 18.02 & 0.000 & $\begin{array}{l}\text { Ballyhonock vs. Lough Aderry } \\
\text { Lough Aderry vs. College }\end{array}$ & $\begin{array}{l}0.000 \\
0.000\end{array}$ \\
\hline
\end{tabular}

Gross internal examination of all tumour-bearing rudd revealed creamy-white nodules in either the spleen or the pancreas of a small number of the rudd with skin tumours. Histological examination showed that these nodules were also squamous cell carcinomas. Histological preparations of the viscera of additional, macroscopically healthy rudd, revealed further visceral tumours. The prevalence of visceral tumours observed was $7.4 \%(20 / 270), 0.2 \%(1 / 610)$ and $0.4 \%$ $(2 / 463)$ at Ballyhonock Lake, Lough Aderry, and College Lake, respectively, but the differences in prevalence were not statistically significant $(p>0.05)$.

There was no statistical association between skin and visceral tumours $(\mathrm{p}>0.05)$.

Only a few fish were found with both skin and visceral tumours: $1 / 270$ rudd $(0.4 \%)$ from Ballyhonock Lake, and 3/610 rudd ( $0.5 \%$ ) from Lough Aderry, proportions which were not significantly different to one another; none were found in College Lake.

\section{Neoplasms and rudd size}

The length of the rudd in the total sample of 1343 ranged from 5.0 to $21.9 \mathrm{~cm}$; fish of 11.0 to $15.9 \mathrm{~cm}$ were most frequently caught $(\mathrm{p}<0.05)$ (Fig. 1). The 55 skin tumour-bearing rudd ranged from 8.0 to $19.9 \mathrm{~cm}$, and those of 11.0 to $11.9 \mathrm{~cm}$ were most frequently observed, while the 23 visceral tumour-bearing rudd ranged from 9.0 to $17.9 \mathrm{~cm}$, most frequently 13.0 to $13.9 \mathrm{~cm}$. Only $4 \mathrm{fish}$, ranging between 13.0 and $20.9 \mathrm{~cm}$, were found with both skin and visceral
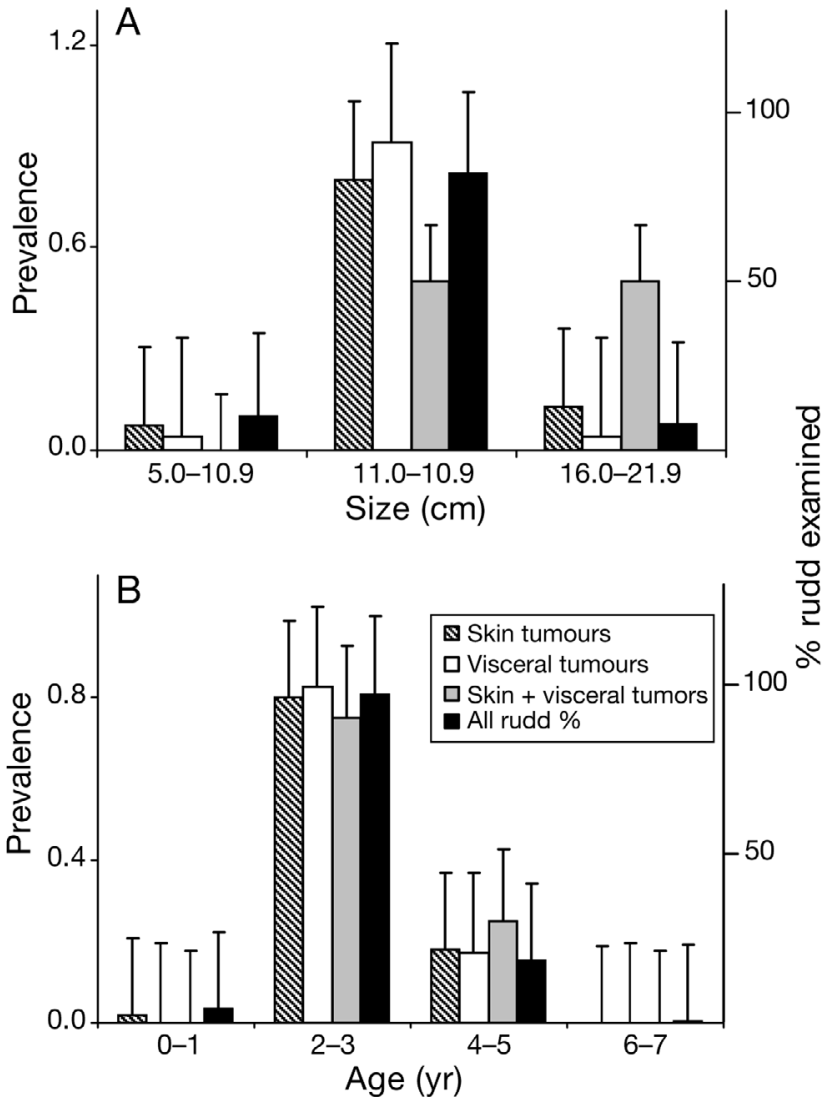

Fig. 1. Scardinius erythrophthalamus. (A) Size and (B) age frequency $(\%)$ distributions of all rudd sampled, and prevalence of skin tumours, visceral tumours, and both skin and visceral tumours in sampled individuals 
tumours. The prevalence of neither skin tumours, nor skin and visceral tumours together related significantly to size of the rudd ( $p>0.05)$ (Table 1). However, in the case of rudd with visceral tumours only, prevalence was significantly greater in the 11.0 to $15.0 \mathrm{~cm}$ size range than either the 5.0 to $10.9 \mathrm{~cm}$ or 16.0 to $21.9 \mathrm{~cm}$ size ranges $(p<0.05)$.

\section{Neoplasms and age of rudd}

The rudd sampled from the 3 lakes ranged in age from $0+$ to $7 \mathrm{yr}$ old; most fish were in the $2-3 \mathrm{yr}$ age group ( $<$ < 0.05) (Fig. 1). No tumour-bearing fish were represented in the 6-7 yr age group. Skin tumours were found in fish aged 1-5 $\mathrm{yr}_{\text {; }}$ most (27/55) were observed in $2 \mathrm{yr}$ olds. Visceral tumours were found in fish aged 2-4 $\mathrm{yr}^{\text {; }}$ most (14/23) were observed in $3 \mathrm{yr}$ olds. Fish bearing both skin and visceral tumours were found in the 2,3 , and $5 \mathrm{yr}$ age groups. The prevalence of rudd with skin tumours only, or visceral tumours only, or both skin and visceral tumours did not vary over the different age groups $(p>0.05)$ (Table 1).

\section{Neoplasms and sex of rudd}

The female:male sex ratio of all rudd bearing tumours (1:1), and the sex ratio of rudd bearing skin tumours $(1: 1.50)$ were both higher than in all healthy rudd (1:1.86); and at Ballyhonock Lake, the single lake from which there were sufficient data for statistical

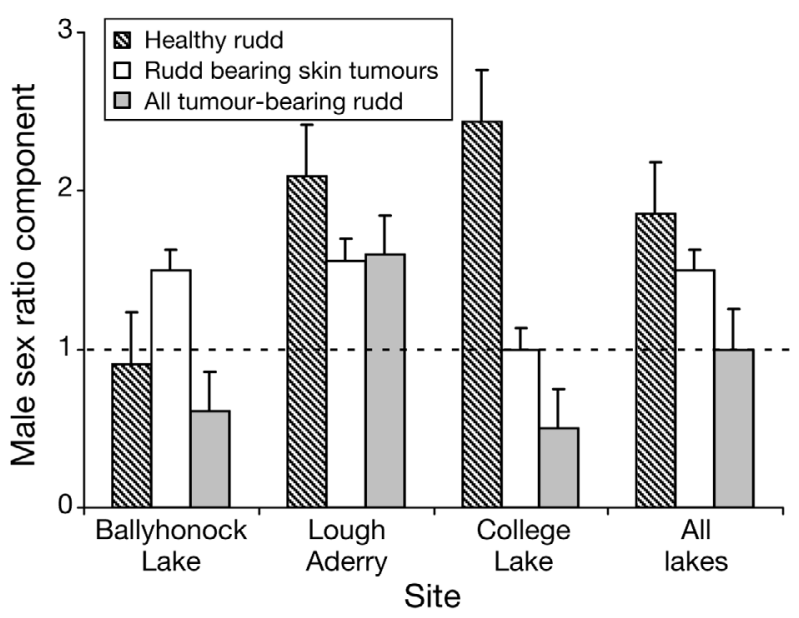

Fig. 2. Scardinius erythrophthalamus. Male component of the female:male sex ratio for healthy rudd, rudd bearing skin tumours and all tumour-bearing fish in Ballyhonock Lake, Lough Aderry, College Lake, and the 3 lakes combined. Dashed line at $y=1$ indicates the female component inference, the sex ratio of 1:0.43 in rudd bearing visceral tumours was higher than the ratio of 1:0.90 in healthy rudd in that lake (Fig. 2, Tables $2 \& 3$ ).

All healthy rudd. The female:male sex ratio of healthy rudd, combined from the 3 study lakes was 1:1.86 (441 females, 820 males). In the individual lakes, the sex ratio in Ballyhonock Lake was 1:0.9 (143 females, 127 males), which was significantly different to that of the combined lakes $(\mathrm{p}<0.05)$, whereas at Lough Aderry, the sex ratio was 1:2.0 (200 females, 400 males), and at College Lake it was 1:2.4 (137 females, 326 males), neither of which differed from the sex ratio of the lakes combined.

All tumour-bearing rudd. The female:male sex ratio of tumour-bearing rudd combined from the 3 lakes was 1:1 (37 females, 37 males), which was significantly different to the 1:1.86 ratio of the healthy rudd. In the individual lakes, the 1:0.61 ratio (18 females, 11 males) at Ballyhonock Lake and the 1:1.16 ratio (15 females, 24 males) in Lough Aderry, respectively, did not differ significantly from the sex ratios of healthy fish in those lakes. The numbers of female and male tumour-bearing fish from College Lake were too low for comparative inference (Table 2).

Skin tumours only. The female:male sex ratio of rudd bearing skin tumours, combined from the 3 lakes, was 1:1.5 (22 female, 33 male), which was higher than the 1:1.86 ratio of healthy rudd $(p<0.05)$, suggesting a selective adverse effect of the carcinoma on male survival. In College Lake as well, the 1:1 sex ratio was higher than the 1:2.4 ratio of healthy rudd in that lake ( $p$ < 0.05). However, in Ballyhonock Lake the 1:1.5 ratio of fish bearing skin tumours was lower than that of healthy rudd, $(p<0.05)$, while at Lough Aderry, the sex ratio of skin tumour-bearing rudd did not differ significantly from that of healthy rudd ( $p>0.05)$.

Visceral tumours only. At Ballyhonock Lake, the female:male sex ratio of rudd bearing visceral tumours, (1:0.43), was higher than the 1:0.9 ratio of healthy rudd at that lake $(p<0.05)$. The numbers of fish bearing visceral tumours from Lough Aderry and College Lake were too low for statistical inference.

\section{Neoplasms and season/year}

The prevalence of squamous cell carcinoma in rudd, combined from the 3 study lakes by season over a period of 25 mo did not fluctuate significantly between seasons ( $\mathrm{p}>0.05)$ : spring: $11.4 \%(27 / 236)$; summer: $5.5 \%(28 / 506)$; autumn: $3.1 \%(12 / 391)$; and winter: $7.1 \%(15 / 210)$. Nor did the prevalence of squamous cell carcinoma vary significantly over the 3 sample years: $2.5 \%$ in $1986 ; 6.6 \%$ in 1987 , and $6.9 \%$ in 1988 $(\mathrm{p}>0.05)$. 
Table 2. Scardinius erythrophthalamus. Prevalence of females and males with skin tumours only, visceral tumours only, and both skin and visceral tumours from the 3 sampling sites, and goodness of fit measures $\left(\chi^{2}\right)$ for tumour prevalence among the sexes $(n=6, d f=1)$

\begin{tabular}{|lcccc|}
\hline Study site & Sex & $\begin{array}{c}\text { Skin } \\
\text { tumours }\end{array}$ & $\begin{array}{c}\text { Visceral } \\
\text { tumours }\end{array}$ & $\begin{array}{c}\text { Skin + visceral } \\
\text { tumours }\end{array}$ \\
\hline Ballyhonock lake & Female & 2.8 & 9.8 & 0.0 \\
Lough Aderry & Male & 4.7 & 4.7 & 0.8 \\
& Female & 8.0 & 0.0 & 0.5 \\
College lake & Male & 6.1 & 0.2 & 0.5 \\
& Female & 1.5 & 1.5 & 0.0 \\
$\chi^{2}$ & Male & 0.6 & 0.0 & 0.0 \\
$\mathrm{p}$ & & 0.04 & 2.88 & 1.60 \\
& & 0.841 & 0.090 & 0.206 \\
\hline
\end{tabular}

observed at Ballyhonock Lake than at either Lough Aderry or College Lake $(\mathrm{p}<0.05)$ (Tables $1 \& 4)$.

Argulus sp., a branchiuran ectoparasite, was found on the skin of 7 healthy rudd, and on one fish with a skin tumour, out of a total of 1343 rudd sampled (Table 4).

\section{Water quality}

Daytime temperatures ranged from 5 to $25^{\circ} \mathrm{C}$, highest in summer and lowest in winter. The temperatures did not differ significantly between the lakes,

\section{Parasitic infections in rudd}

Metacercariae of the trematode Posthodiplostomum cuticola, seen as black spots, were encysted in the skin and fins of some rudd, both healthy and with tumours, from Ballyhonock Lake, Lough Aderry, and almost all rudd from College Lake, and were also observed histologically in the viscera of some fish. The prevalence of $P$. cuticola metacercaria in the skin was significantly lower at Lough Aderry than either Ballyhonock or College Lake ( $\mathrm{p}<0.05)$, but did not differ significantly between either season or year $(p>0.05)$. Observed $P$. cuticola metacercarial prevalence in the viscera did not vary between the seasons, lakes, or years $(\mathrm{p}>$ 0.05). Rudd with both tumours and the parasite were rarely observed, but parasite prevalence correlated positively with prevalence of visceral carcinomas ( $p>$ 0.05) (Tables 1, 4 \& 5).

Sphaerospora sp. (J. Lom, pers. comm.), a myxosporean parasite, was observed histologically in the kidney of both non-neoplastic and tumour- bearing fish, whether involving skin or viscera. Higher prevalence of the parasite in the kidney of all rudd was or between sample years, nor associate with the prevalence of tumours or parasites of the rudd ( $p>0.05)$.

The $\mathrm{pH}$ varied widely, from 6.72 to 10.60 , highest in summer and lowest in winter $(\mathrm{p}<0.05)$. The $\mathrm{pH}$ did not vary between the lakes or between sample years, nor associated with the prevalence of either tumours or parasites $(p>0.05)$.

Water hardness at Ballyhonock lake was significantly greater than at either Lough Aderry or College Lake $(p<0.05)$. Water hardness was greater in winter/spring than in autumn ( $\mathrm{p}<0.05)$, and greater hardness was observed in 1987 than in 1986 ( $p<0.05)$. Water hardness associated positively with the prevalence of visceral tumours and skin metacercariae in rudd ( $\mathrm{p}<0.05$ ) (Tables $5 \& 6$ ).

DO levels also varied widely, and, even though they were recorded only during daytime, values below $2 \mathrm{mg}$ $\mathrm{l}^{-1}$ were recorded in Lough Aderry in October 1988, when DO was $1.7 \mathrm{mg} \mathrm{l}^{-1}$ at one site (16.14\% saturation). Supersaturation was also recorded: up to $18.0 \mathrm{mg} \mathrm{l}^{-1}$ (214\% saturation) was recorded in July 1987. Daytime oxygen levels did not vary between seasons ( $\mathrm{p}>0.05)$. However, significantly lower oxygen readings were

Table 3. Scardinius erythrophthalamus. Goodness of fit measures $\left(\chi^{2}\right)$ of differences among the combined sex ratio of healthy rudd from the 3 sites versus the sex ratios of healthy rudd from the individual sites $(\mathrm{n}=4, \mathrm{df}=2)$, and the goodness of fit measures for difference between the sex ratios of healthy versus tumour-bearing rudd at the individual sites, and for the combined sex ratio for the 3 sample sites $(n=4, d f=2)$. - insufficient data for statistical inference

\begin{tabular}{|c|c|c|c|c|c|c|c|c|}
\hline & \multicolumn{2}{|c|}{$\begin{array}{l}\text { Ballyhonock } \\
\text { Lake }\end{array}$} & \multicolumn{2}{|c|}{$\begin{array}{l}\text { Lough } \\
\text { Aderry }\end{array}$} & \multicolumn{2}{|c|}{$\begin{array}{l}\text { College } \\
\text { Lake }\end{array}$} & \multicolumn{2}{|c|}{ Combined } \\
\hline & $\chi^{2}$ & $\mathrm{p}$ & $\chi^{2}$ & $\mathrm{p}$ & $\chi^{2}$ & $\mathrm{p}$ & $\chi^{2}$ & $\mathrm{p}$ \\
\hline $\begin{array}{l}\text { Combined vs. individual site } \\
\text { sex ratio of healthy rudd }\end{array}$ & 14.21 & 0.000 & 0.451 & 0.502 & 2.50 & 0.114 & - & - \\
\hline \multicolumn{9}{|c|}{ Sex ratio of healthy vs. tumour-bearing rudd } \\
\hline Skin tumours & 6.67 & 0.010 & 2.74 & 0.098 & 23.60 & 0.000 & 1.45 & 0.229 \\
\hline Visceral tumours & 10.66 & 0.001 & - & - & - & - & - & - \\
\hline All tumours & 3.40 & 0.065 & 2.30 & 0.129 & 61.17 & 0.000 & 10.97 & 0.001 \\
\hline
\end{tabular}


Table 4. Prevalence of parasitic infections in neoplastic and non-neoplastic rudd Scardinius erythrophthalamus

\begin{tabular}{|lcc|}
\hline $\begin{array}{l}\text { Parasite species } \\
\text { Infection site }\end{array}$ & Neoplasm & $\begin{array}{c}\text { Prevalence } \\
(\%)\end{array}$ \\
\hline $\begin{array}{l}\text { Posthodiplostomulum cuticola } \\
\text { Skin }\end{array}$ & Skrematoda) \\
Viscera & Visceral & 0.07 \\
& None & 0.13 \\
Sphaerospora sp. (Protozoa) & Skin & \\
Kidney & Visceral & 0.13 \\
& None & 0.11 \\
& & \\
Argulus sp. (Crustacea) & Skin & 0.02 \\
Skin & Visceral & 0.00 \\
& None & 0.01 \\
\hline
\end{tabular}

recorded in 1988 than in 1987 ( $p<0.05$ ), and readings in Lough Aderry were significantly lower than in either Ballyhonock Lake or College Lake ( $<<0.05)$.

BOD, ammonia, nitrate, orthophosphates and chlorophyll a levels recorded showed that all 3 lakes were eutrophic. BOD values ranged from 0.1 to 10.7 , but did not differ significantly between seasons or between lakes ( $p>0.05)$, but were higher in 1987 than in 1988 $(p<0.05)$. Ammonia level did not vary over the seasons ( $p>0.05)$. However, highest ammonia concentrations were recorded at Lough Aderry and lowest in Ballyhonock $(\mathrm{p}<0.05)$, and significantly greater levels were recorded in 1986 than in 1988 ( $\mathrm{p}<$ 0.05). Nitrate values did not vary significantly between season, year or lake $(\mathrm{p}>0.05)$. However nitrate concentrations associated positively with visceral metacercariae ( $p<0.05)$. Phosphate values did not vary significantly between either season or year ( $p>0.05)$, but levels were significantly higher in College Lake than either Ballyhonock Lake or Lough Aderry ( $p$ $<0.05)$. Chlorophyll a values were significantly higher in 1986 than in 1987 ( $p<0.05)$, but did not vary significantly between either season or year $(\mathrm{p}>0.05)$.

\section{Soil radioactivity}

Radioactive isotopes were detected in soil near each of the 3 lakes, and results for thorium series, uranium238, radium-226, bismuth-214, potassium-40, and caesium-137 are sum- marised in Table 7 . The results were within expected levels, and were comparable to those observed elsewhere in Ireland (I. McAulay pers. comm.) The caesium values indicated fallout from weapons testing, and not from the Chernobyl accident, as no caesium134 was found (I. McAulay pers. comm.)

\section{DISCUSSION}

During the 2 yr survey on 3 lakes in east Cork, skin tumours were found in rudd. The tumours were diagnosed as squamous cell carcinomas on the basis of their histopathology (Hanjavanit \& Mulcahy 2004). This malignant neoplasm is unusual, in that cyprinid tumours are rarely malignant (Hoole et al. 2001). In their study of the biology of rudd from 171 sites in Ireland, Kennedy \& Fitzmaurice (1974) sampled 8 fish from College Lake, 29 from Lough Aderry, and 13 from Ballyhonock Lake, but no tumours were recorded at that time. The fact that no tumours were observed in 1974 even in the relatively small samples of rudd from Lough Aderry and College Lake, raises the possibility that the occurrence of squamous cell carcinoma in the rudd is a more recent phenomenon in these lakes.

The prevalence of rudd with skin tumours in Lough Aderry $(6.7 \%)$ was higher than that in Ballyhonock Lake $(3.7 \%)$ and College Lake $(0.9 \%)$, while the prevalence of visceral tumour-bearing fish in Ballyhonock Lake $(7.4 \%)$ was higher than that in Lough

Table 5. Scardinius erythrophthalamus. Significant associations observed when regression analysis was conducted among the histopathological parameters, and on the environmental parameters and the histopathological parameters of 1986-1988 data set $(\mathrm{n}=25, \mathrm{df}=1,24$; test assumptions met of normality and homoscedastic variance; $\mathrm{R}^{2}=$ dependent variance, $\%$; $t$-value $\geq \pm 1.71, F \geq 4.26$; $\mathrm{p} \leq 0.05$ test accepted). BOD $=$ biochemical oxygen demand

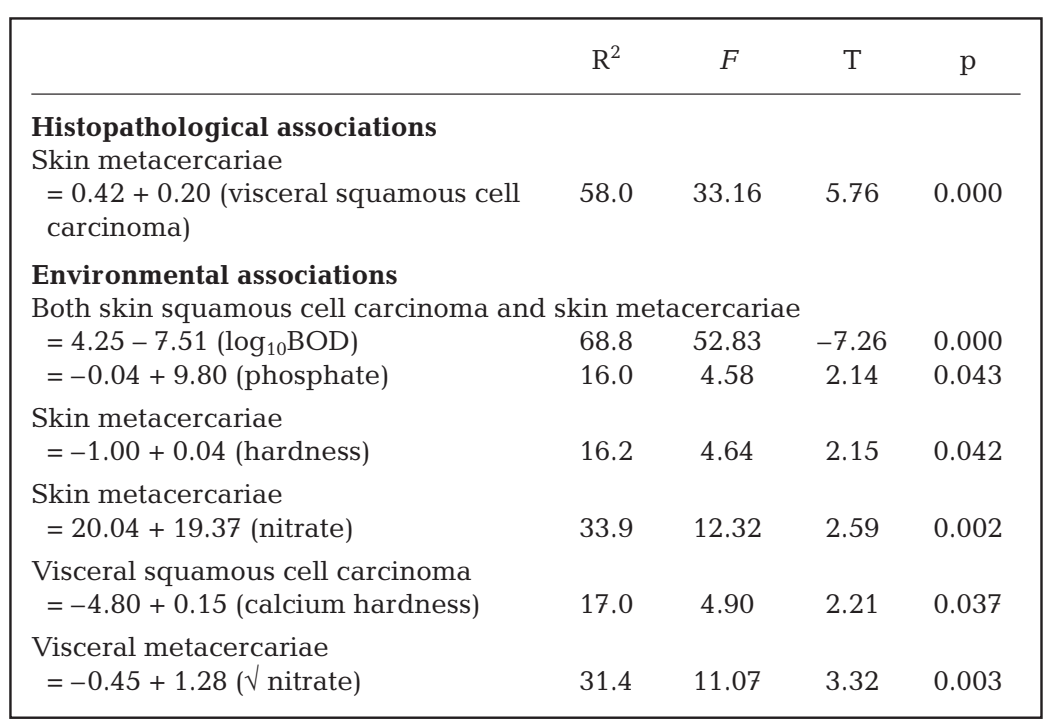


Table 6. Significant variance observed in the various environmental parameters among the seasons $(\mathrm{n}=25 ; \mathrm{df}=3,22)$, between the lakes $(\mathrm{n}=25 ; \mathrm{df}=2,23)$, and years $(\mathrm{n}=25 ; \mathrm{df}=2,23)$ in the $1986-1988$ data set. $F \geq 3.05$ : significant variation at $\mathrm{p} \leq 0.05$; $\left.\chi^{2} \geq 5.99\right)$. -: insufficient data for statistical inference

\begin{tabular}{|c|c|c|c|c|c|c|}
\hline Parameter & $F$ & $\mathrm{p}$ & $\chi^{2}$ & $\mathrm{p}$ & Comparison & $\mathrm{p}$ \\
\hline \multicolumn{7}{|l|}{ Season } \\
\hline \multirow{5}{*}{ Air temperature } & 57.54 & 0.000 & _- & _- & Winter vs. spring & 0.000 \\
\hline & & & & & Winter vs. summer & 0.000 \\
\hline & & & & & Winter vs. autumn & 0.000 \\
\hline & & & & & Spring vs. summer & 0.000 \\
\hline & & & & & Summer vs. autumn & 0.000 \\
\hline \multirow[t]{3}{*}{ Water temperature } & 21.62 & 0.000 & 34.97 & 0.000 & Winter vs. summer & 0.000 \\
\hline & & & & & Spring vs. summer & 0.000 \\
\hline & & & & & Summer vs. autumn & 0.000 \\
\hline \multirow[t]{3}{*}{$\mathrm{pH}$} & 9.47 & 0.000 & - & - & Winter vs. summer & 0.000 \\
\hline & & & & & Spring vs. summer & 0.041 \\
\hline & & & & & Summer vs. autumn & 0.000 \\
\hline \multirow[t]{4}{*}{ Hardness } & 9.268 & 0.000 & - & - & Winter vs. summer & 0.007 \\
\hline & & & & & Winter vs. autumn & 0.015 \\
\hline & & & & & Spring vs. summer & 0.000 \\
\hline & & & & & Spring vs. autumn & 0.001 \\
\hline \multirow[t]{4}{*}{ Calcium hardness } & 8.61 & 0.000 & - & - & Winter vs. summer & 0.002 \\
\hline & & & & & Winter vs. autumn & 0.008 \\
\hline & & & & & Spring vs. summer & 0.002 \\
\hline & & & & & Spring vs. autumn & 0.009 \\
\hline \multicolumn{7}{|c|}{ 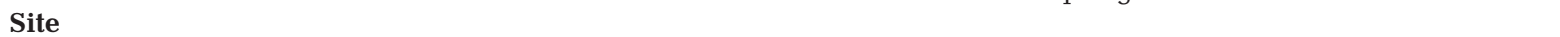 } \\
\hline \multirow[t]{2}{*}{ Dissolved oxygen } & 10.92 & 0.000 & 12.66 & 0.002 & Ballyhonock vs. Lough Aderry & 0.010 \\
\hline & & & & & Lough Aderry vs. College & 0.000 \\
\hline \multirow[t]{2}{*}{ Percent saturated oxygen } & 9.55 & 0.000 & - & - & Ballyhonock vs. Aderry & 0.024 \\
\hline & & & & & Lough Aderry vs. College & 0.000 \\
\hline Alkalinity & 3.28 & 0.045 & - & - & Ballyhonock vs. Lough Aderry & 0.040 \\
\hline \multirow[t]{2}{*}{ Calcium hardness } & 5.10 & 0.009 & 10.66 & 0.005 & Ballyhonock vs. Lough Aderry & 0.022 \\
\hline & & & & & Lough Aderry vs. College & 0.021 \\
\hline Ammonia & 4.58 & 0.014 & - & - & Ballyhonock vs. Lough Aderry & 0.011 \\
\hline \multirow{2}{*}{ Phosphate } & 35.96 & 0.000 & - & - & Lough Aderry vs. College & 0.000 \\
\hline & & & & & Lough Aderry vs. College & 0.000 \\
\hline \multicolumn{7}{|l|}{ Year } \\
\hline Dissolved oxygen & 3.33 & 0.042 & - & - & 1987 vs. 1988 & 0.033 \\
\hline Percent saturated oxygen & 5.85 & 0.005 & - & - & 1987 vs. 1988 & 0.004 \\
\hline Biochemical oxygen demand & 5.83 & 0.005 & & & 1987 vs. 1988 & 0.004 \\
\hline Hardness & 6.90 & 0.002 & & & 1986 vs. 1987 & 0.001 \\
\hline \multirow[t]{2}{*}{ Calcium hardness } & 4.79 & 0.012 & & & 1986 vs. 1987 & 0.011 \\
\hline & & & & & 1986 vs. 1988 & 0.043 \\
\hline \multirow{2}{*}{ Ammonia } & 8.284 & 0.001 & & & 1986 vs. 1988 & 0.001 \\
\hline & & & & & 1987 vs. 1988 & 0.011 \\
\hline Chlorophyll a & 7.49 & 0.001 & & & 1986 vs. 1987 & 0.001 \\
\hline
\end{tabular}

Aderry $(0.2 \%)$ and College Lake $(0.4 \%)$. However, these differences were not statistically significant. Only a few cases from Ballyhonock Lake and Lough Aderry showed both skin and visceral tumours, with prevalence of 0.4 and $0.5 \%$, respectively, and there were none in College Lake. It is probable that the visceral tumours are metastases from skin tumours. The results may thus indicate a more chronic development of the neoplasm in Ballyhonock Lake than in Lough Aderry and College Lake. Data for tumour prevalence must be considered minimum prevalences, because while all macroscopic tumours were detected, additional neoplasms were detected in histological sections of the viscera. It is possible that some microscopic skin tumours, and further microscopic visceral tumours went undetected, since only macroscopic skin lesions were sectioned for histology, and organ samples only, not complete viscera, were sectioned.

Male and female rudd appear to grow at a similar rate, and to similar sizes in the lakes under study: Kennedy \& Fitzmaurice (1974) found that from any one body of water, there was no clear differentiation of growth between males and females. There was no correlation between the length of the rudd and prevalence of either skin or visceral tumours. The skin tumour was frequently observed in smaller fish, size 11.0 to $11.9 \mathrm{~cm}$, whereas the visceral tumour occurred mainly in the medium sized fish, 13.0 to $13.9 \mathrm{~cm}$; the 4 
Table 7. Mean $\pm \mathrm{SD}$ natural radioactivity, $\left(\mathrm{Bq} \mathrm{kg}^{-1}\right)$, in soil samples near the 3 study lakes, August 1988

\begin{tabular}{|lccc|}
\hline Isotope & $\begin{array}{c}\text { Ballyhonock } \\
\text { Lake }\end{array}$ & $\begin{array}{c}\text { Lough } \\
\text { Aderry }\end{array}$ & $\begin{array}{c}\text { College } \\
\text { Lake }\end{array}$ \\
\hline Thorium series & $23 \pm 1$ & $24 \pm 1$ & $27 \pm 2$ \\
Uranium-238 & $34 \pm 9$ & $15 \pm 6$ & $35 \pm 10$ \\
Radium-226 & $31 \pm 9$ & $38 \pm 8$ & $22 \pm 6$ \\
Bismuth-214 & $22 \pm 2$ & $19 \pm 2$ & $23 \pm 2$ \\
Potassium-40 & $380 \pm 20$ & $400 \pm 16$ & $390 \pm 20$ \\
Caesium-137 & $74 \pm 2$ & $23 \pm 3$ & $54 \pm 3$ \\
\hline
\end{tabular}

fish with both skin and visceral tumours were longer, supporting the hypothesis that the visceral metastases spread later than the skin tumours. The prevalence of both skin tumours and visceral tumours decreased as the length of fish increased, and the range of length of tumour-bearing rudd was more restricted at both the lower and the higher ends than the range of length of all rudd combined. In contrast, Poulet et al. (1994) recorded that the frequency of orocutaneous papillomas and carcinomas in brown bullheads Ictalurus nebulosus increased with the length of the fish. No evidence of healing lesions was found in the rudd. It is possible that the neoplasm in rudd resulted in mortalities, thus explaining the decrease in tumour prevalence as the length increased.

Healthy rudd were aged from $0+$ to $7 \mathrm{yr}$, mostly 2,3 and $4 \mathrm{yr}$ olds. Rudd of up to $10 \mathrm{yr}$ of age are common in many waters in Ireland (Kennedy \& Fitzmaurice 1974), but longevity varies with population density, which appears to be high in the lakes studied. Skin tumours occurred in 1 to 5 yr olds, mainly 2 yr olds. Visceral tumours were found in 2 to 4 yr olds, mostly $3 \mathrm{yr}$ olds, while fish with both skin and visceral tumours were in the 2,3 , and 5 yr age groups. There was no statistically significant correlation between age and tumour development, but the data indicate that skin tumours may be the primary tumours and develop earlier than visceral metastases; and also that the neoplasm may cause mortality, in that no 6 or 7 yr old rudd was found with a neoplasm. Baumann et al. (1990) considered the scarcity of brown bullheads, over $4 \mathrm{yr}$ of age in the Black River, Ohio to be due to the prevalence of hepatic carcinoma.

The sex ratio results suggest a selective adverse effect on male survival, in which male hormones may play a part. While Nunez et al. (1989) discussed the higher rates of certain neoplasms in female fish due to the promoter oestradiol, Kimura et al. (1984) found the prevalence of chromatophoromas in croakers Nibea mitsukurii in coastal waters in Japan to be higher in males than in females. Poulet et al. (1994) found no difference between the prevalences of papillomas and carcinomas in male and female brown bullheads, but papillomatosis in roach Rutilus rutilus was 7.5 times higher in male than in females (Kortet et al. 2002), a finding supported by Vainikka et al. (2004) and Korkea-aho et al. (2006). Among squamous cell carcinomas, Herman (1988) described enzootic squamous cell carcinomas in mature male rainbow smelt Osmerus mordax in a pond in Maine, US, and Morrison \& Macdonald (1995) also reported a squamous cell carcinoma in the jaw of a male rainbow smelt $O$. mor$d a x$, and speculated about male hormonal influence. Roberts (1972) reported a carcinoma in a male Salmo salar, while Budd et al. (1975) found a squamous cell carcinoma on the jaw of one male out of 4899 yellow perch Perca flavescens from Lake Huron, North America. The rudd tumours occurred in both immature and mature fish ranging from $1+$ to $5+$ yr old. Rudd maturity depends on age, and also on growth rate (Kennedy \& Fitzmaurice 1974). Females aged $2+$ yr are immature, but $2+$ males are mature and all $3+$ and older fish are mature.

Squamous cell carcinoma was found in rudd throughout the year with irregular fluctuations, which do not appear to relate to season. From the pooled data, the neoplasm does not appear to be influenced by the spawning period, which in Ireland is from late May to mid July (Kennedy \& Fitzmaurice 1974). Malignant lymphoma in pike Esox lucius L. in Ireland likewise does not show a seasonal pattern (Mulcahy 1976), although it does in North America (Sonstegard 1976).

The parasitic infections in the rudd were uneven in distribution. The digenetic trematode metacercaria of Posthodiplostomulum cuticola is known to occur occasionally in rudd in Ireland (Kennedy \& Fitzmaurice 1974), but they noted $100 \%$ infections in rudd from College Lake in 1974, as was also found in this study. The authors (op. cit.) attributed this to the shallow, weedy conditions in College Lake, favourable for the snail primary host and the heron secondary host. The parasite was commonly found embedded within the epidermal tissue of skin and, in some cases, the worm penetrated and embedded in the viscera of the unaffected healthy fish. In a few cases, metacercariae were found in the proximity of a tumour mass. According to Miller \& Wellings (1971), the ectoparasite on fish could 'elicit an inflammatory pre-neoplastic lesion which later developed into a true neoplasm or ectoparasites may function as vectors for viral transmission.' Hard et al. (1979) found metacercariae of a digenetic trematode embedded within fish tumour tissue and suggested that it could have been a case of parasitic aetiology, but this was not conclusive. In the present study 'blackspot' infections correlated positively with visceral, but not with skin tumours. The ectoparasitic fish louse Argulus sp. was rarely found on either neoplastic 
or healthy fish. However, Argulus tends to readily detach from the skin when the fish host is captured, so its impact on the rudd cannot be judged from the numbers recorded in this study. Ahne (1985) showed that Argulus foliaceus could act as a mechanical vector of spring viraemia of carp virus in carp. Thus, should a virus be involved in the rudd carcinoma, transmission by ectoparasite is hypothetically possible. Pickering \& Willoughby (1977) stated that $A$. foliaceus might not be directly responsible for epidermal lesions found in perch Perca fluviatilis but that it was acting as a vector in transmitting an infectious disease. Sphaerospora sp. infections were common in the kidneys of both healthy and neoplastic rudd, but the data were insufficient to conduct correlations. Sphaeropora spp. are common generally in cyprinid kidneys (Hoole et al. 2001). Stressed fish are more prone to parasitic infections, while parasitic infections themselves decrease the resistance of fish, and may enhance susceptibility to a neoplasm.

Water quality in the 3 study lakes was generally favourable for rudd, which like other cyprinids are relatively tolerant. However, conditions would have been stressful for the rudd for periods during the year. $\mathrm{pH}$ was variable but exceeded 10.5 on occasion in both Ballyhonock Lake and Lough Aderry. All 3 lakes were eutrophic, judging by results for chlorophyll $a$, nitrate, and phosphate (Hoole et al. 2001) and for BOD, which exceeded the EU-recommended maximum for cyprinids of $6 \mathrm{mg} \mathrm{O}_{2} \mathrm{l}^{-1}$. The lakes are situated in an agricultural catchment, receiving the runoff from agricultural activities. Recorded DO levels on occasion were below the guideline minimum of $5 \mathrm{mg}$ $\mathrm{O}_{2} \mathrm{l}^{-1}$, while, on other occasions, the waters were supersaturated. These results probably do not record the extremes of DO, since the samples were always taken in the late morning, and so would not have detected either the oxygen decline due to phytoplankton respiration during the early morning, nor the highest oxygen levels of late afternoon due to photosynthesis. Ammonia levels were unlikely to have been a problem, being within the tolerance values for cyprinids (Hoole et al. 2001). The harmful effects of ammonia are related to both $\mathrm{pH}$ and temperature, but after conversion of the ammonium results to unionised ammonia $\left(\mathrm{NH}_{3}\right)$, concentrations were well below the critical value of $0.44 \mathrm{~g} \mathrm{l}^{-1}$ threshold for lethal concentration $\left(\mathrm{LC}_{50}\right)$. The results overall did not indicate a relationship between trophic status of the water and the prevalence of squamous cell carcinoma in rudd. However, environmental stressors are known to reduce immunocompetence (Anderson 1996), and so stress, due to water quality extremes, is likely to have rendered the rudd more susceptible to oncogenic influences. Statistical associations observed between water quality parameters and squamous cell carcinoma prevalence included (1) water hardness, which was higher at Ballyhonock Lake than at either Lough Aderry or College Lake, associated positively with the prevalence of visceral tumours and skin metacercariae; (2) nitrate concentrations associated positively with visceral metacercariae; and (3) BOD, associated negatively with prevalence of skin tumours coupled with metacercariae. However, the significance of these statistical associations is speculative.

Radioactivity is a physical form of water pollution, which is relatively rare, because the possible sources are very closely controlled. Very low levels of radioactivity occur naturally or as a result of radioactive particles washed out of the air by rain (Environmental Control and Public Health 1975). In the present study, the radioactive isotopes measured in the soil samples surrounding the 3 lakes were considered to be a very low dose for the people living on such soils (I. McAulay, pers. comm.), and results did not suggest an association between natural radioactivity and the prevalence of tumours.

The squamous cell carcinomas in the rudd have a strong genetic component, since these neoplasms have not been seen in other fish species in the lakes sampled. Species specificity in fish tumours is a well-established phenomenon (Schlumberger 1957).

There is evidence for viral aetiology in many plaquetype epidermal neoplasms (Walker 1969, Sano et al. 1985, Ahne et al. 1990, Lee \& Whitfield 1992, Harshbarger et al. 1993, Anders \& Yoshimizu 1994, Morrison et al. 1998). However, while Baumann et al. (1996) considered it probable that a virus was involved in papillomas in brown bullheads Ictalurus nebulosus and white suckers Catostomus commersoni, they considered that the aetiology was multifactorial, as the disease development was influenced by chemical contamination. Premdas \& Metcalfe (1996) likewise proposed a multifactorial aetiology for papillomas in white suckers based on their overall findings, even though the results of experimental transmission experiments using cellfree filtrates supported viral involvement; no viruses were visible in either donor or induced papillomas. Both Kortet et al. (2002) and Vainikka et al. (2004) found that epidermal papillomatosis in roach Rutilus rutilus was more prevalent in polluted environments, although Vainikka et al. (2004) raised the possibility that a virus might also be involved. On the other hand, Poulet et al. (1994) found no consistent correlation between orocutaneous papillomas and carcinomas of brown bullheads and level of chemical contamination. Pinkney et al. $(2001,2004)$ studied hepatomas, papillomas and squamous cell carcinomas in brown bullheads in a number of US watersheds, and concluded that the skin tumour prevalences were indicative of exposure 
to contaminants, including polyaromatic hydrocarbons (PAHs). Epidermal papillomatosis in dab Limanda limanda is an ICES (International Council for the Exploration of the Sea) indicator of environmental changes in the North Atlantic coastal areas (Bucke et al. 1996).

Evidence for viral aetiology in globular types of epidermal neoplasm, including squamous cell carcinomas, is weak, and the neoplasms tend to occur in polluted environments (Harshbarger et al. 1993). No virus particles were seen in the squamous cell carcinomas in this study, and preliminary experiments to transmit the neoplasm using cell-free filtrates were unsuccessful (Hanjavanit \& Mulcahy 2004).

Black et al. (1982) suggested that copper and other metals catalyse the formation of a new compound(s) that is carcinogenic in fish. However, no obvious sources of copper or other metals were present in the lake catchments in this study. Harshbarger (1972) proposed that nitrosamines may be a potent group of chemical carcinogens in aquatic environments. Nnitroso compounds are widely used experimentally as carcinogens, and may be produced by the reaction of amines with nitrites (Ayanaba \& Alexander 1974). Ungerer et al. (1974) described the nitrosation of the herbicide $\mathrm{N}$-methyl-N-(2 benzothiazolyl)-urea with nitrite, the N-nitroso product being carcinogenic in Wistar rats. Spitsbergen \& Wolfe (1995) suggested that nitrosamines as well as PAHs contribute to both skin and liver tumor development in brown bullheads, and Pinkney et al. (2004) proposed that nitrosamines, among other chemicals, should be investigated in the study sites, where they had studied papillomas and squamous cell carcinomas in brown bullheads. Mitogenic N-nitroso compounds have been found in the muscle of fish exposed to high nitrate concentrations (De Flora \& Arillo 1983). Fish are known to produce methylamines, and it is possible that carcinogenic methylnitrosamines are formed with nitrites in the hypereutrophic waters of the lakes in this study. It is probably relevant that eutrophication is a relatively recent phenomenon in Ireland, resulting from intensification in agriculture, and the fact that Kennedy \& Fitzmaurice (1974) did not observe squamous cell carcinoma in the study lakes supports the possibility that the occurrence of squamous cell carcinoma in the study lakes may also be of more recent origin.

Another possibility is that toxins, produced by freshwater algae in the study lakes, could have been involved in the rudd neoplasm aetiology. Many planktonic algae produce toxins, which can cause a wide range of pathologic effects in other organisms (Landsberg 2002). Some toxins are known to cause dermatologic effects (El-Saadi et al. 1995, Pitois et al. 2001, Van Apeldoorn et al. 2007), while others are tumorigenic, some as carcinogens and others as tumour promoters
(Falconer et al. 1989, Sekijima et al. 1999, Pitois et al. 2001, Landsberg 2002). Most is known about the microcystins, which cause liver damage and promote tumour formation in liver, as well as in other organs including mouse skin (Nishiwaki-Matsushima et al. 1992, Malbrouck \& Kestemont 2006, Van Apeldoorn et al. 2007). Microcystin LR was linked to liver disease in Atlantic salmon in netpens (Chorus \& Bartram 1999), and also liver and kidney damage in carp (Rabergh et al. 1991). Much less is known about the effects of the many other toxins, including nodularins, anatoxins, cylindrospermopsins, saxitoxins, aplysiatoxins and lyngbatoxins. Some hyperplasia of bile ducts and fibrotic lesions was observed in the liver of both healthy and tumour-bearing rudd in the present study, which could perhaps have been caused by algal toxins. Landsberg (2002), in a comprehensive review of effects of harmful algal blooms on aquatic organisms, expressed surprise that aquatic biotoxins are rarely considered as aetiological agents of tumour induction, considering that many aquatic animals are chronically exposed to tumour-promoting biotoxins.

Therefore, while the results of the present study overall did not indicate a relationship between trophic status of the water and the prevalence of squamous cell carcinoma in rudd, nor between the natural radioactivity and the prevalence of the rudd tumours, it would be interesting to measure the concentration of nitrosamines in water, sediment or fish, and also to examine the toxicity of blue-green algae from the study lakes, for their possible oncogenic role.

Acknowledgements. We thank R. McNamara for fishing and fieldwork, N. Buttimer for collecting water samples and helping with water chemistry, and I. McAulay, Department of Pure and Applied Physics, Trinity College, Dublin, for soil radioactivity analysis. We acknowledge a grant from the Irish Cancer Society to M.F.M.

\section{LITERATURE CITED}

Ahne W (1985) Argulus foliaceus L. and Piscicola geometra L. as mechanical vectors of spring viraemia of carp virus (SVCV). J Fish Dis 8:241-242

Ahne W, Anders M, Halder M, Yoshimizu M (1990) Isolation of picornavirus-like particles from the European smelt Osmerus eperlanus (L.). J Fish Dis 13:167-168

American Public Health Association (APHA) (1985) Standard methods for the examination of water and wastewater, 16th edn. APHA, American Water Works Association, Water Pollution Control Federation, Washington, DC

Anders K, Yoshimizu M (1994) Role of viruses in the induction of skin tumours and tumour-like proliferations in fish. Dis Aquat Org 19:215-232

Anderson DP (1996) Environmental factors in fish health: immunological aspects. In: Iwama G, Nakahishi T (eds) The fish immune system. Academic Press, San Diego, CA, p 289-310 
Ayanaba A, Alexander M (1974) Transformations of methylamines and formation of a hazardous product, dimethylnitrosamine, in samples of treated sewage and lake water. J Environ Qual 3:83-89

Baumann PC, Harshbarger JC, Hartman KJ (1990) Relationship between tumors and age in brown bullhead populations from two Lake Erie tributaries. Sci Total Environ 94:71-87

Baumannn PC, Smith IR, Metcalfe CD (1996) Linkages between chemical contaminants and tumors in benthic Great Lakes fish. J Great Lakes Res 22(2):131-152

Black JJ, Evans ED, Harshbarger JC, Zeigel RF (1982) Epizootic neoplasms in fishes from a lake polluted by copper mining wastes. J Natl Cancer Inst 69:915-926

Brown ER, Hazdra JJ, Keith L, Greenspan I, Kwapinski JBG, Beamer P (1973) Frequency of fish tumours found in a polluted watershed as compared to nonpolluted Canadian waters. Cancer Res 33:189-198

Bucke D, Vethaak D, Lang T, Mellergaard S (1996) Common diseases and parasites of fish in the North Atlantic: training guide for identification. ICES Cooperative Research Report 19. International Council for the Exploration of the Sea, Copenhagen, p 1-27

Budd J, Schroder JD, Dukes KD (1975) Tumors of yellow perch. In: Ribelin WE, Migaki G (eds) The pathology of fishes. University of Wisconsin Press, Madison, WI, p 895-906

Chorus I, Bartram J (eds) (1999) Toxic Cyanobacteria in water, a guide to their public health consequences, monitoring and management. World Health Organisation publication, Spon Press, London

Couch JA, Harshbarger JC (1985) Effects of carcinogenic agents on aquatic animals: an environmental and experimental overview. J Environ Sci Health C Environ Carcinog Rev 3:63-105

De Flora S, Arillo A (1983) Mutagenic and DNA-damaging activity in muscle of trout exposed in vivo to nitrite. Cancer Lett 20:147-155

El Saadi O, Esterman AJ, Cameron S, Roder DM (1995) Murray River water, raised cyanobacterial cell counts, and gastrointestinal and dermatological symptoms. Med J Aust 182:122-125

Environmental Control and Public Health (1975) Clean and dirty water. Water analysis standard and treatment. Open University Press, Milton Keynes, p 28-42

Falconer IR, Runnegar MTC, Buckley T, Huyn Van L, Bradshaw P (1989) Using activated carbon to remove toxicity from drinking water containing cyanobacterial blooms. Am Water Works Assoc J 81:102-105

Hanjavanit C (1991) Squamous cell carcinoma in rudd Scardinius erythrophthalmus (L.) PhD thesis, National University of Ireland

Hanjavanit C, Mulcahy MF (2004) Squamous cell carcinoma in rudd Scardinius erythrophthalmus: histopathology, ultrastructure, and transmission. Dis Aquat Org 61: $215-226$

Hanjavanit C, Mulcahy MF, Doyle CT (1990) Squamous-cell carcinoma in rudd Scardinius erythrophthalmus. Dis Aquat Org 8:155-156

Hard GC, Williams R, Lee J (1979) Histopathology of a superficial fish 'tumour' found during a cancer survey of demersal species in Port Philip Bay, Victoria, Australia. J Fish Dis 2:455-467

Harshbarger JC (1972) Work of the Registry of Tumours in Lower Animals with emphasis on fish neoplasms. Symp Zool Soc Lond 30:285-303

Harshbarger JC, Spero PM, Wolcott NM (1993) Neoplasms in wild fish from the marine ecosystem emphasizing environ- mental interactions. In: Couch JA, Fournie JW (eds) Pathobiology of marine and estuarine organisms. CRC Press, Boca Raton, FL, p 157-176

Herman RL (1988) Squamous cell carcinoma in rainbow smelt Osmerus mordax. Dis Aquat Org 5:71-73

Hoole D, Bucke D, Burgess P, Wellby I (2001) Diseases of carp and other cyprinid fishes. Fishing News Books, Blackwell Science, Oxford

Kennedy M, Fitzmaurice P (1974) Biology of the rudd, Scardinius erythrophthalmus (L) in Irish waters. Proc R Ir Acad B 74(18):245-303

Kimura I, Taniguchi H, Kumai I, Tomita N and others (1984) Correlation of epizootiological observations with experimental data: chemical induction of chromatophoromas in the croaker, Nibea mitsukurii. In: Hoover KL (ed) Use of small fish in carcinogenicity testing: proceedings of a symposium, Bethesda, MD (1981). Natl Cancer Inst Monogr 65:139-154

Korkea-aho TL, Partanen JM, Kiviniemi V, Vainikka A, Taskinen J (2006) Association between environmental stress and epidermal papillomatosis of roach Rutilus rutilus. Dis Aquat Org 72:1-8

Kortet R, Vainikka A, Taskinen J (2002) Epizootic cutaneous papillomatosis in roach Rutilus rutilus: sex and size dependence, seasonal occurrence and between-population differences. Dis Aquat Org 52:185-190

Landsberg JH (2002) The effects of harmful algal blooms on aquatic organisms. Rev Fish Sci 10(2):113-390

> Lee S, Whitfield PJ (1992) Virus-associated spawning papillomatosis in smelt, Osmerus eperlanus L., in the River Thames. J Fish Biol 40:503-510

Mackereth FJH, Heron J, Talling JF (1978) Water analysis. FBA Scientific Publication 36. Freshwater Biological Association, Ambleside

Malbrouck C, Kestemont P (2006) Effects of microcystins on fish. Environ Toxicol Chem 25(1):72-86

Malins DC, McCain BB, Brown DW, Chan S and others (1984) Chemical pollutants in sediments and diseases of bottomdwelling fish in Puget Sound, Washington. Environ Sci Technol 18:705-713

$>$ Miller BS, Wellings SR (1971) Epizootiology of tumours on flathead sole (Hippoglossoides elassodon) in East Sound Oreas Island, Washington. Trans Am Fish Soc 100: 247-266

> Morrison CM, Macdonald CA (1995) Epidermal tumours on rainbow smelt and Atlantic salmon from Nova Scotia. J Aquat Anim Health 7:241-250

Morrison CM, Leggiadro CT, Martell DJ (1996) Visualisation of viruses in tumors of rainbow smelt Osmerus mordax. Dis Aquat Org 26:19-23

Mulcahy MF (1976) Epizootiological studies of lymphomas in northern pike in Ireland. Prog Exp Tumor Res 20:120-140

Nishiwaki-Matsushima R, Ohta T, Nishiwaki S, Suganima M and others (1992) Liver tumor promotion by the cyanobacterial cyclic peptide toxin microcystin-LR. J Cancer Res Clin Oncol 118:420-424

$>$ Nunez O, Hendricks JD, Arbogast DN, Fong AT, Lee BC, Bailey GS (1989) Promotion of aflatoxin B1 hepatocarcinogenesis in rainbow trout by $17 \beta$ estradiol. Aquat Toxicol 15:289-302

> Pickering AD, Willoughby LG (1977) Epidermal lesions and fungal infection of the perch, Perca fluviatilis L., in Windermere. J Fish Biol 11:349-354

> Pinkney AE, Harshbarge JC, May EB, Malancon MJ (2001) Tumor prevalence and biomarkers of exposure in brown bullheads (Ameiurus nebulosus) from the Tidal Potomac River Watershed. Environ Toxicol Chem 20:1196-1205 
Pinkney AE, Harshbarger JC, May EB, Reichert, WL (2004) Tumor prevalence and biomarkers of exposure and response in brown bullhead (Ameiurus nebulosus) from the Anacostia river Washington, DC and Tuckahoe River, Maryland, USA. Environ Toxicol Chem 23(3):638-647

Pitois S, Jackson MH, Wood BJB (2001) Sources of the eutrophication problems associated with toxic algae: an overview. J Environ Health 64(5):25-32

Poulet FM, Wolfe MJ, Spitsbergen JM (1994) Naturally occurring orocutaneous papillomas and carcinomas of brown bullheads (Ictalurus nebulosus) in New York State. Vet Pathol 31:8-18

Premdas PD, Metcalfe CD (1996) Experimental transmission of epidermal lip papillomas in white sucker, Catostomus commersoni. Can J Fish Aquat Sci 53:1018-1029

Rabergh CMI, Bylund G, Eriksson JE (1991) Histopathological effects of microcystin-LR a cyclic peptide toxin from the cyanobacterium (blue-green alga) Microcystis aeruginosa, on common carp (Cyprinus carpio L.). Aquat Toxicol 20:131-146

Roberts RJ (1972) Oral carcinomas in a salmon (Salmo salar L.). Vet Rec 91(8):199

Sano T, Fukuda H, Furukawa M (1985) Herpesvirus cyprini: biological and oncogenic properties. Fish Pathol 20:381-388

Editorial responsibility: Thomas Lang,

Cuxhaven, Germany
Schlumberger HG (1957) Tumors characteristic for certain animal species. A review. Cancer Res 8:657-754

Sekijima M, Tsutsumi T, Yoshida T, Harada T, Tashiro, F, Chen G, Yu S, Ueno Y (1999) Enhancement of glutathione S-transferase placental-form positive liver cell foci development by microcystin-LR in aflatoxin B1-initiated rats. Carcinogenesis 20(1):161-165

Sonstegard RA (1976) Studies of the etiology and epizootiology of lymphosarcoma in Esox (Esox lucius L. and Esox masquinongy). Prog Exp Tumor Res 20:141-155

Spitsbergen JM, Wolfe MJ (1995) The riddle of hepatic neoplasia in brown bullheads from relatively unpolluted waters in New York state. Toxicol Pathol 23:716-725

Ungerer O, Eisenbrand G, Preussmann R (1974) Zur Reaktion von Nitrit mit Pestiziden. Z Krebsforsch 81:217-224

Vainikka A, Kortet R, Taskinen J (2004) Epizootic cutaneous papillomatosis, cortisol and male ornamentation during and after breeding in the roach Rutilus rutilus. Dis Aquat Org 60:189-195

Van Apeldoorn ME, Van Egmond, HP, Speijers GJA, Bakker GJI (2007) Toxins of cyanobacteria. Mol Nutr Food Res 51(1):7-60

Walker R (1969) Virus associated with epidermal hyperplasia in fish. Natl Cancer Inst Monogr 31:195-207

Submitted: February 20, 2007; Accepted: March 1, 2008

Proofs received from author(s): June 26, 2008 